\title{
Computer simulation of energy use, greenhouse gas emissions, and process economics of the fluid milk process ${ }^{1}$
}

\author{
P. M. Tomasula, ${ }^{* 2}$ W. C. F. Yee, † A. J. McAloon, $†$ D. W. Nutter, $\ddagger$ and L. M. Bonnaillie \\ ${ }^{*}$ Dairy and Functional Foods Research Unit, and \\ †Engineering and Scale-up, Process and Economics Research Support Group, United States Department of Agriculture, \\ Agricultural Research Service, Eastern Regional Research Center, 600 E. Mermaid Lane, Wyndmoor, PA 19038 \\ ¥University of Arkansas, Mechanical Engineering Department, Fayetteville 72701
}

\begin{abstract}
Energy-savings measures have been implemented in fluid milk plants to lower energy costs and the energyrelated carbon dioxide $\left(\mathrm{CO}_{2}\right)$ emissions. Although these measures have resulted in reductions in steam, electricity, compressed air, and refrigeration use of up to $30 \%$, a benchmarking framework is necessary to examine the implementation of process-specific measures that would lower energy use, costs, and $\mathrm{CO}_{2}$ emissions even further. In this study, using information provided by the dairy industry and equipment vendors, a customizable model of the fluid milk process was developed for use in process design software to benchmark the electrical and fuel energy consumption and $\mathrm{CO}_{2}$ emissions of current processes. It may also be used to test the feasibility of new processing concepts to lower energy and $\mathrm{CO}_{2}$ emissions with calculation of new capital and operating costs. The accuracy of the model in predicting total energy usage of the entire fluid milk process and the pasteurization step was validated using available literature and industry energy data. Computer simulation of small (40.0 million L/yr), medium (113.6 million L/yr), and large (227.1 million L/yr) processing plants predicted the carbon footprint of milk, defined as grams of $\mathrm{CO}_{2}$ equivalents $\left(\mathrm{CO}_{2 \mathrm{e}}\right)$ per kilogram of packaged milk, to within $5 \%$ of the value of $96 \mathrm{~g}$ of $\mathrm{CO}_{2 \mathrm{e}} / \mathrm{kg}$ of packaged milk obtained in an industry-conducted life cycle assessment and also showed, in agreement with the same study, that plant size had no effect on the carbon footprint of milk but that larger plants were more cost effective in producing milk. Analysis of the pasteurization step showed that increasing the percentage regeneration of the pasteurizer from 90 to $96 \%$
\end{abstract}

\footnotetext{
Received September 29, 2012.

Accepted January 25, 2013.

${ }^{1}$ Mention of trade names or commercial products in this publication is solely for the purpose of providing specific information and does not imply recommendation or endorsement by the US Department of Agriculture. The USDA is an equal opportunity provider and employer.

${ }^{2}$ Corresponding author: peggy.tomasula@ars.usda.gov
}

would lower its thermal energy use by almost $60 \%$ and that implementation of partial homogenization would lower electrical energy use and $\mathrm{CO}_{2 \mathrm{e}}$ emissions of homogenization by 82 and $5.4 \%$, respectively. It was also demonstrated that implementation of steps to lower non-process-related electrical energy in the plant would be more effective in lowering energy use and $\mathrm{CO}_{2 \mathrm{e}}$ emissions than fuel-related energy reductions. The model also predicts process-related water usage, but this portion of the model was not validated due to a lack of data. The simulator model can serve as a benchmarking framework for current plant operations and a tool to test cost-effective process upgrades or evaluate new technologies that improve the energy efficiency and lower the carbon footprint of milk processing plants.

Key words: greenhouse gas, milk processing, specific energy consumption, economics

\section{INTRODUCTION}

High concentrations of greenhouse gases (GHG) in the atmosphere, which absorb and emit the thermal infrared radiation reflected by the earth's surface, clouds, or atmosphere, have been implicated as a cause of global climate change (IPCC, 2007). Although GHG occur naturally, the increases in global average temperatures are very likely due to the increases in GHG concentrations resulting from anthropogenic or human activities (IPCC, 2007). Water vapor, carbon dioxide $\left(\mathrm{CO}_{2}\right)$, methane $\left(\mathrm{CH}_{4}\right)$, nitrous oxide $\left(\mathrm{N}_{2} \mathrm{O}\right)$, and ozone are naturally occurring $\mathrm{GHG}$, but $\mathrm{CO}_{2}, \mathrm{CH}_{4}$, and $\mathrm{N}_{2} \mathrm{O}$ are represented in increased amounts due to human activities: $83.4 \%$ of the total GHG are $\mathrm{CO}_{2}$ emissions resulting from fossil fuel burning for electricity production, industry, transportation, and commercial and residential needs; $9.5 \%$ are $\mathrm{CH}_{4}$ emissions from agriculture, landfills, coal, oil, and gas operations; and $4.9 \%$ are $\mathrm{N}_{2} \mathrm{O}$ emissions from agriculture and fossil fuel use. Other GHG (2.1\%) include industrial gases such as the halocarbons, which are typically used as refrigerants, and may contain fluorine, bromine, or chlorine (EPA, 2012). Greenhouse gas emissions for all gases are usually 
reported in terms of $\mathrm{CO}_{2}$ equivalents $\left(\mathbf{C O}_{2 \mathrm{e}}\right)$ because of their differences in properties and lifetimes in the atmosphere. In terms of the global warming potential over a 100-yr time horizon, $\mathrm{CH}_{4}$ is 25 times more potent than $\mathrm{CO}_{2}, \mathrm{~N}_{2} \mathrm{O}$ is 298 times more potent than $\mathrm{CO}_{2}$, and halocarbons are from 124 to 14,800 times more potent than $\mathrm{CO}_{2}$ (IPCC, 2007).

In the United States, agricultural practices contribute $6.3 \%$ of total GHG emissions mainly due to emissions of $\mathrm{CH}_{4}$ and $\mathrm{N}_{2} \mathrm{O}$, with a much smaller contribution from $\mathrm{CO}_{2}$ emissions (EPA, 2012). Using life cycle analysis (LCA), Thoma et al. (2012) demonstrated that the entire dairy sector contributes approximately $1.9 \%$ of total US GHG emissions. The total carbon footprint of milk, which was defined as the sum of the GHG emissions calculated for each stage of the fluid milk supply chain per unit quantity of milk, was reported as 17.6 pounds of $\mathrm{CO}_{2 \mathrm{e}} / \mathrm{gal}$ of fluid milk consumed (2.12 $\mathrm{kg}$ of $\mathrm{CO}_{2 \mathrm{e}} / \mathrm{kg}$ of fluid milk consumed). A second LCA conducted by the Aurora dairies (Cashman et al., 2009) also reported a carbon footprint of milk of 17.6 pounds of $\mathrm{CO}_{2 \mathrm{e}} /$ gal $\left(2.12 \mathrm{~kg}\right.$ of $\mathrm{CO}_{2 \mathrm{e}} / \mathrm{kg}$ of milk) for organic milk production. Both LCA showed that the bulk of GHG emissions in fluid milk production occurred on the farm as $\mathrm{CH}_{4}$ because of enteric fermentation of cows and, to a lesser extent, manure handling and $\mathrm{N}_{2} \mathrm{O}$ because of feed production.

However, the bulk of GHG emissions beyond the farmgate are mainly energy-related $\mathrm{CO}_{2}$ emissions because of fossil fuel use. Natural gas and fossil fuelgenerated electricity are used to process and package milk; diesel fuels are used to transport and distribute milk; and electricity is used for cold storage of milk at the plant or distribution point and in the consumer's home. Some emissions are due to leakage of refrigerants. For milk processing and packaging alone, the carbon footprint of milk, obtained by LCA, was reported as $96 \mathrm{~g}$ of $\mathrm{CO}_{2 \mathrm{e}} / \mathrm{kg}$ of packaged milk (Tan et al., 2011; Thoma et al., 2012). Considering that approximately 26 billion $\mathrm{kg}$ of fluid milk is processed in the United States each year (IDFA, 2007) and that 553 million $t$ of milk are produced worldwide (FAO, 2010), emitting a total of about 1,328 million $\mathrm{t}$ of $\mathrm{CO}_{2}$, reduction of energy usage in the processing sector would lower $\mathrm{CO}_{2 \mathrm{e}}$ emissions significantly as well as the costs associated with milk processing.

Efforts to mitigate GHG emissions throughout the processing sector have led to the implementation of best practices in plants, following an energy audit to establish a performance baseline or benchmark that follows the exchange of energy and mass between the plant and the environment over time. Use of best practices have helped processing plants reduce energy use in the form of steam, electricity, compressed air, and refrigeration by 5 to 30\% (Doty and Turner, 2009; Tomasula and Nutter, 2011). To compare benchmarked individual plants to the average industry performance, $\mathrm{Xu}$ and Flapper (2009) reported energy information data for fluid milk plants throughout the United States and other dairying countries. The energy performance in the United States, reported in terms of the specific energy consumption (SEC), the energy usage of the entire plant divided by the total fluid milk production, ranged from 0.2 to $6.0 \mathrm{MJ} / \mathrm{kg}$ of fluid milk. This large variation in performance indicates significant opportunities for energy savings in this sector ( $\mathrm{Xu}$ and Flapper, 2009).

To achieve further reductions in energy, a model that simulates the fluid milk process would allow benchmarking of current plant operations and examination of the contributions of the individual process unit operations, or related sections of a plant, to its total energy performance (Tomasula and Nutter, 2011). The model may also be used as a tool to investigate process operating conditions or process modifications to lower GHG emissions and energy use.

Process simulation is a well-established, powerful tool that has been used by the chemical process industries for years to optimize current plant operations or to assist in the design of new plants. A process simulator is a computer program that links modules representing the unit operations to perform mass and energy balances at each unit operation and over the entire process. Each module is a mathematical representation of the physical processes that occurs in the unit operation. Once constructed, the mass and energy flows of each component of the process and, in some programs, the costs associated with the process, may be predicted for each unit operation and over the entire process. However, adaptation of commercial software for chemical processing to food processing scenarios requires significant modification before use (Cheng and Friis, 2007). The goal of this study was to develop a customizable process simulation tool for the fluid milk industry, based on commercial software, to benchmark GHG emissions by calculating the carbon footprint for milk and energy usage and economics for the total process operation and for each unit operation; to validate the model using literature and industry data; and to apply the model in a variety of processing scenarios.

\section{MATERIALS AND METHODS}

\section{Model Development}

The commercial software package, SuperPro Designer (http://www.intelligen.com; version 8.5 build 6; Intelligen Inc., Scotch Plains, NJ), which contains models 


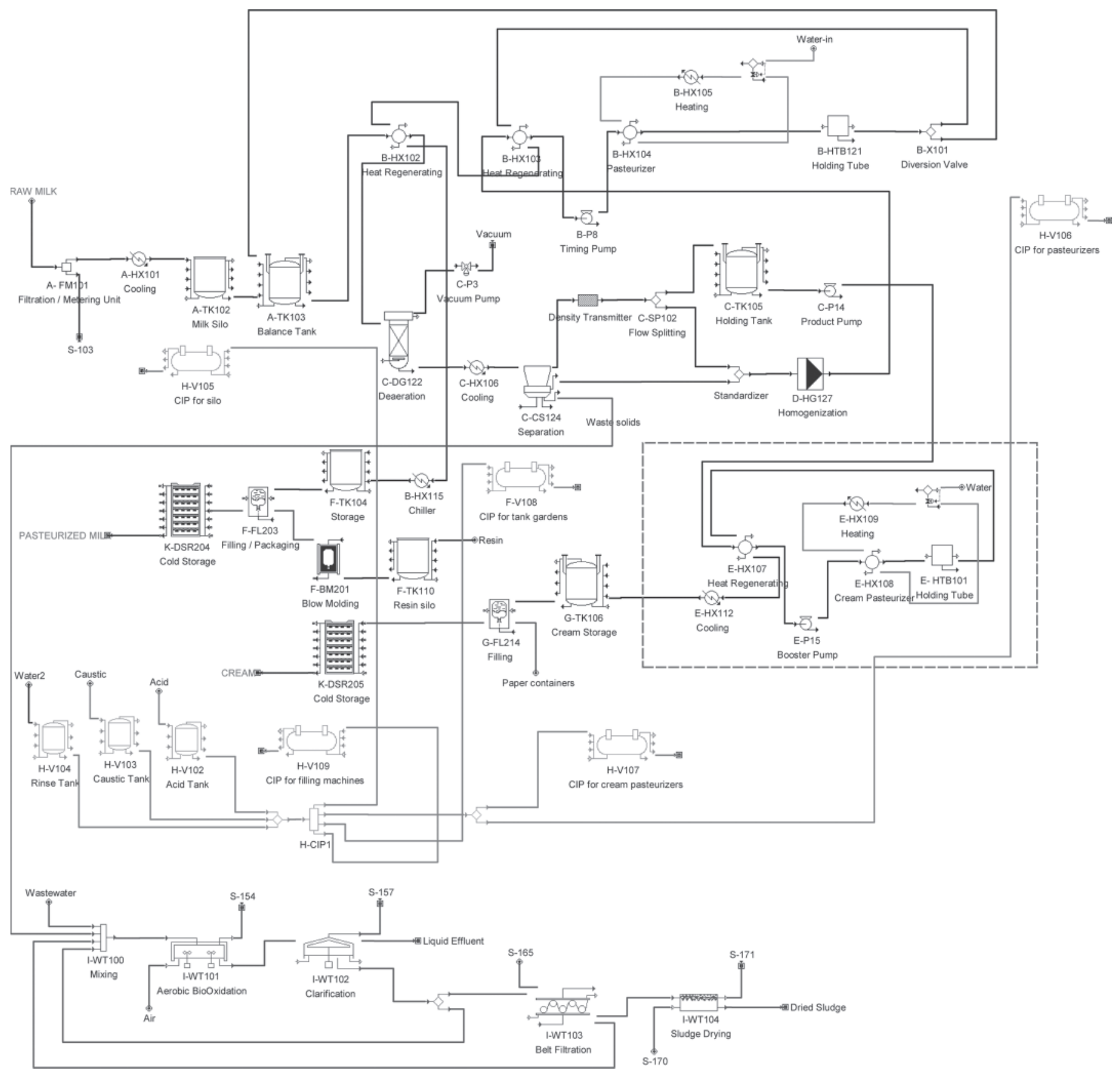

Figure 1. Process flow sheet of the fluid milk model. Full homogenization is used. CIP = cleaning-in-place.

for 140 general unit operations for equipment, such as heaters and coolers, heat exchangers, flow mixers and splitters, homogenizers, centrifuges, and tanks, all of which are applicable to the development of a flow sheet and simulation of the fluid milk process, was used in this study. The models for the unit operations are represented by icons. The icons were used to develop the flow sheet diagram of the fluid milk process, as shown in Figure 1, with an overview of the unit operations and operating conditions used in this study for a base model processing 40.0 million L/yr given in Table 1.

\section{Description of the Model by Section}

The base fluid milk process depicted by the flow sheet of Figure 1 is roughly separated into sections for milk reception and storage, milk standardization, milk homogenization, milk pasteurization, milk packaging, 
Table 1. Overview of unit operations in Figure 1 for the base fluid milk model processing 40,000,000 L/yr of whole milk ${ }^{1}$

\begin{tabular}{|c|c|c|}
\hline Unit ID & Description $^{2}$ & Detail \\
\hline A-HX101 & Raw milk cooler & $3.3^{\circ} \mathrm{C}$ outlet temperature; glycol cooling medium \\
\hline A-TK102 & Silo tanks & 16-h residence time \\
\hline A-TK103 & Balance tank & 1-h residence time \\
\hline B-HX102 & First preheat regenerating section & $\begin{array}{l}64^{\circ} \mathrm{C} \text { exit temperature of cold milk; } 7.0^{\circ} \mathrm{C} \text { exit temperature of pasteurized milk; } 99.8 \mathrm{~m}^{2} \text { heat } \\
\text { transfer area }\end{array}$ \\
\hline B-HX103 & Second preheat regenerating section & $\begin{array}{l}72.3^{\circ} \mathrm{C} \text { exit temperature of cold milk; } 68.6^{\circ} \mathrm{C} \text { exit temperature of pasteurized milk; } 12.1 \mathrm{~m}^{2} \text { heat } \\
\text { transfer area }\end{array}$ \\
\hline B-HX104 & Milk pasteurizer & $77.2^{\circ} \mathrm{C}$ exit temperature of cold milk; $5.0 \mathrm{~m}^{2}$ heat transfer area \\
\hline B-HTB121 & Milk holding tube & 22 -s residence time \\
\hline C-DG122 and -HX106 & Deaerator & Temperature decrease of $8^{\circ} \mathrm{C}$ \\
\hline C-CS124 & Centrifugal separator & $\begin{array}{l}162.5 \mathrm{~L} / \mathrm{min} \text { throughput; } 40 \% \text { fat content in overflow; } 0.05 \% \text { fat content in underflow; } 81.7 \% \text { of } \\
\text { cream remix back with skim milk }\end{array}$ \\
\hline C-TK105 & Cream holding tank & 4-h residence time \\
\hline D-HG127 & Homogenizers & 198 bar pressure drop; $63.7^{\circ} \mathrm{C}$ exit temperature; $52.7-\mathrm{kW}$ power consumption \\
\hline B-HX115 & Chiller & $1.7^{\circ} \mathrm{C}$ outlet temperature; glycol cooling medium \\
\hline F-TK104 & Milk storage tanks & 1.5 -h residence time \\
\hline E-HX107 & Cream preheat regeneration section & $\begin{array}{l}85.0^{\circ} \mathrm{C} \text { exit temperature of cold cream; } 63.6^{\circ} \mathrm{C} \text { exit temperature of pasteurized cream; } 0.4 \mathrm{~m}^{2} \text { heat } \\
\text { transfer area }\end{array}$ \\
\hline E-HX108 & Cream pasteurizer & $90.0^{\circ} \mathrm{C}$ exit temperature of cold cream; $0.07 \mathrm{~m}^{2}$ heat transfer area \\
\hline E-HTB101 & Cream holding tube & 15-s residence time \\
\hline F-BM201 & Blow molding - HDPE gallon jugs & 2,479 jugs per hour; $58 \mathrm{~g}$ of resin per jug; 111-kW operating power \\
\hline F-FL203 & Milk filling/packaging & $25-\mathrm{kW}$ operating power \\
\hline G-FL214 & Cream filling/packaging; paper pint packaging & $3.7-\mathrm{kW}$ operating power \\
\hline K-DSR204, -DSR205 & Cold storage for milk and cream & $4,600-\mathrm{m}^{2}$ storage area; $555-\mathrm{kW}$ refrigeration power \\
\hline H-V106 & CIP tank for cream pasteurizer & $5-\mathrm{kW}$ auxiliary power \\
\hline H-V107 & CIP tank for milk pasteurizer & $5-\mathrm{kW}$ auxiliary power \\
\hline F-V108 & CIP tank for tank gardens & $5-\mathrm{kW}$ auxiliary power \\
\hline H-V109 & CIP tank for filling machines & 5-kW auxiliary power \\
\hline I-WT101 & Aeration tank & 6-h average hydraulic residence time; 23 -h sludge residence time \\
\hline I-WT102 & Clarifier & $1 \%$ solids content \\
\hline I-WT103 & Belt filter press & $15 \%$ solids content \\
\hline I-WT104 & Sludge dryer & $35 \%$ final solids content \\
\hline
\end{tabular}

The first letter of the unit ID identifies the location of the unit in the figure.

응. $\quad{ }^{2} \mathrm{HDPE}=$ high-density polyethylene; CIP = cleaning-in-place. 
storage, cleaning-in-place (CIP) operations, and wastewater treatment. All pipelines, tanks, and equipment for processing are assumed to be constructed of sanitary, food-grade stainless steel and to meet 3-A Standards (McLean, VA; http://www.3-a.org).

Milk Reception and Storage. After the cows are milked, the raw milk is cooled and maintained at a maximum temperature of $7^{\circ} \mathrm{C}$ in a bulk tank at the farm (FDA, 2011), although many fluid milk processors recommend that their suppliers cool milk to $4^{\circ} \mathrm{C}$. It is sampled and checked for quality at the farm and then transported in sanitary stainless steel tanker trucks to the processing plant in an unrefrigerated but insulated tanker truck. Once at the plant, the milk is sampled for bacteria and antibiotics and milk temperature is recorded. It is then pumped from the tanker by a highspeed pump to stainless steel milk silos for storage. A metering unit is placed in the line to monitor the flow. The milk silos are insulated to maintain milk at $4^{\circ} \mathrm{C}$ within a standard time frame of about $24 \mathrm{~h}$ and are available in sizes up to $265,000 \mathrm{~L}$. They are also equipped with an agitator to prevent cream separation. The raw milk is pumped from the silos to a balance tank to ensure a constant supply to the milk standardization and pasteurization section.

Milk Standardization and Pasteurization. Milk standardization is the precise addition of cream to the skim milk through computer process control to yield milk with the desired fat content. To begin the process, the milk from the balance tank is drawn by the timing pump to the first regeneration section of the pasteurizer (preheat section). After heating, a vacuum-deaeration step may be used to remove dissolved air that may cause off-flavors and aromas in the milk or cream products. Because the simulator does not include a module for deaeration, the pressure in the expansion vessel is adjusted to a value that results in a boiling point temperature about $8^{\circ} \mathrm{C}$ below the inlet temperature. The vacuum pump removes the dissolved air, causing the temperature of milk to decrease from 64 to $56^{\circ} \mathrm{C}$. The cooling block following the deaerators is used to model the temperature decrease. The deaerator is followed by a high-speed centrifugal separator designed for efficient separation of cream from milk. The separator ejects waste solids on an hourly basis, which are directed to the waste management section of the plant. The fat content of the cream was assumed as $40 \%$ and that of the skim milk as $0.05 \%$. The cream and skim milk were blended to create $3.25 \%$ milk (whole milk) using a split block in the model. Adjusting the split block appropriately also allows simulation of a plant producing skim or 1 or $2 \%$ milk.

The excess cream is directed to storage and further processing. The cream may be processed into heavy cream, light cream, half and half, buttermilk, and other products.

Homogenization. A high-pressure homogenizer is used to reduce the size of the milk fat globules so that they remain suspended in milk during storage. A 2-stage homogenizer is assumed in the model, with an outlet pressure of $20 \mathrm{MPa}$. For every 4-MPa drop in pressure, milk temperature is increased by $1^{\circ} \mathrm{C}$. The largest size of homogenizer on the market accommodates milk flow rates of up to approximately 30,000 $\mathrm{L} / \mathrm{h}$. Some larger plants have 2 or more homogenizers online to accommodate the larger production rates. An alternative to homogenizers for accommodation of the entire milk stream is partial homogenization, in which only the cream stream is homogenized (Figure 2).

Pasteurization of Milk and Cream. The HTST pasteurizer in this model is simulated by 5 plate heat exchangers in series. The homogenization step completes the regenerative preheating of milk by the pasteurized milk in the second and third heat exchangers. The homogenized milk then enters the final heating section of the pasteurizer, where it is heated to an assumed temperature of $77^{\circ} \mathrm{C}\left(171^{\circ} \mathrm{F}\right)$ and held for $22 \mathrm{~s}$ in a holding tube. The Pasteurized Milk Ordinance (FDA, 2011) mandates a minimum pasteurization temperature for milk of $72^{\circ} \mathrm{C}$ and holding time of $15 \mathrm{~s}$.

While the raw milk is preheated by pasteurized milk in the second and third heat exchangers, it is heated in the pasteurizing heat exchanger by hot water produced by steam heating of water in the final heating step. The percentage regeneration is calculated as follows:

$$
\begin{aligned}
& \text { Percentage regeneration }=\text { temperature }(T) \text { increase } \\
& \text { caused by regeneration/total temperature change in } \\
& \text { milk }=\left(T_{\text {after regeneration }}-T_{\text {feed }}\right) /\left(T_{\text {pasteurization }}-T_{\text {feed }}\right) .
\end{aligned}
$$

Following holding, the pasteurized milk flows to the opposite side of the plate heat exchanger, where it is cooled by regenerative cooling. The pasteurized milk then enters the chilling section, where it is cooled to $4^{\circ} \mathrm{C}$ by cold water chilled using the coolant glycol.

Excess cream is also pasteurized using HTST pasteurization but at a temperature of $90^{\circ} \mathrm{C}$, with a holding time of $15 \mathrm{~s}$ in this study. The percentage regeneration was assumed as $94 \%$ in the regenerator sections of the pasteurizers unless otherwise noted.

Skid-mounted pasteurizer units come in various sizes to accommodate processing capacity and can process up to approximately 34,000 L of milk/h. Processors may have one or more units to handle various products or demand.

Filling/Packaging. In the 40.0 million L/yr base model that was developed for the fluid milk process, 


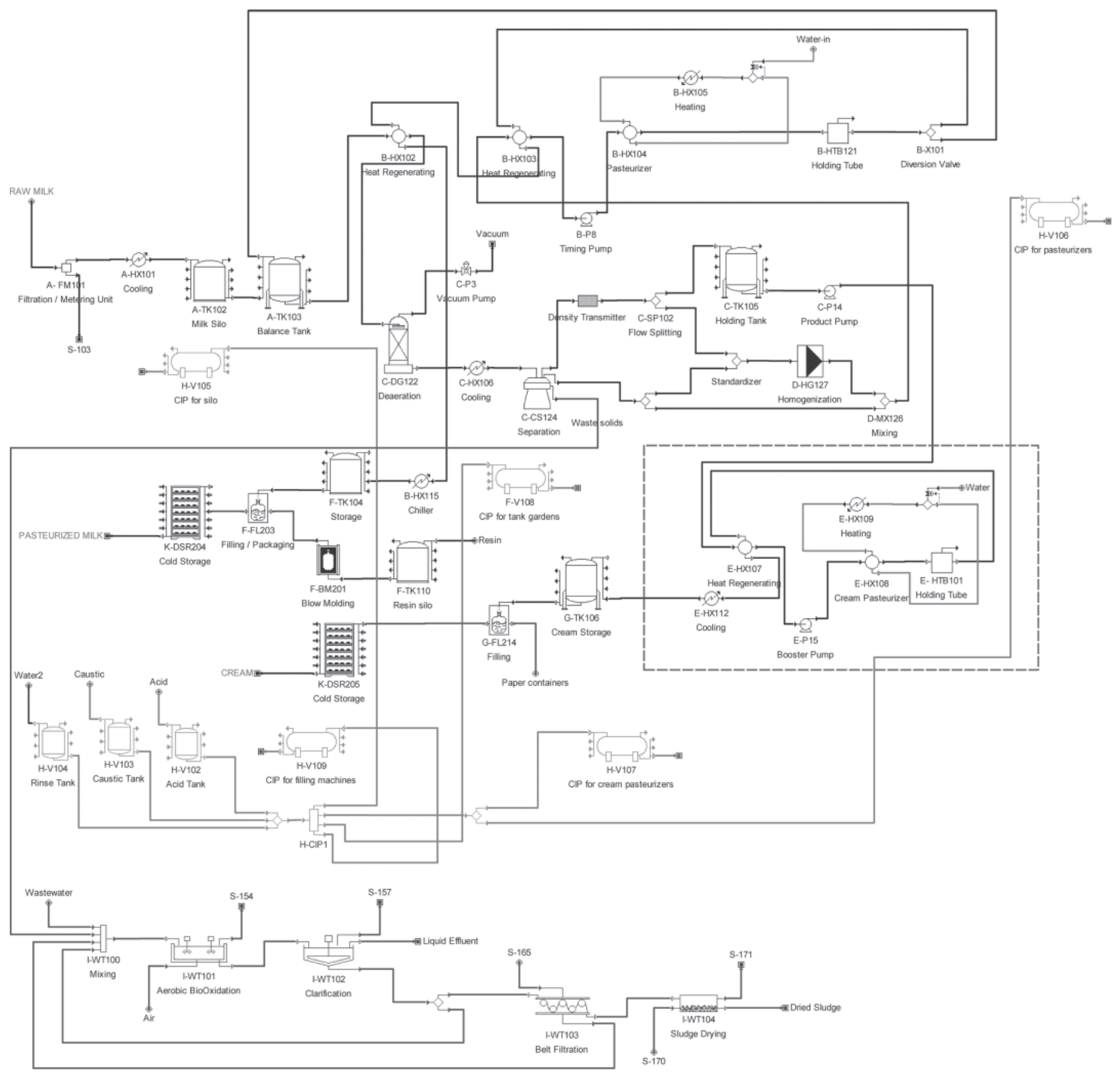

Figure 2. Process flow sheet for the fluid milk process. Partial homogenization is assumed. CIP = cleaning-in-place.

it was assumed that only high-density polyethylene (HDPE) gallon jugs and paper pint packaging for containing whole milk and cream, respectively, were used. The gallon jugs were produced on site through blow molding. Depending on the amount of milk processed, a facility may have one or more blow molders with the feed resin stored in a flat-bottomed tank on site. Fiftyeight grams of resin per gallon jug was assumed (Erba et al. 1997). The paper pint containers for cream were assumed to be purchased. Milk or cream is filled using filling machines. A dairy may have several filling machines.

Cold Storage. After packaging, the milk and cream may be stored on site, delivered to a distribution center, or delivered directly to a retailer. Some plants also store nondairy products such as juices. The simulation model assumes a storage area of up to $4,600 \mathrm{~m}^{2}$ for storing packaged milk at $1.8^{\circ} \mathrm{C}$ for up to $1.5 \mathrm{~d}$, but 
allows the user to enter the size of their storage facility and estimated energy consumption. The Natural Resources Canada (NRCan) Office of Energy Efficiency surveyed energy usage for 17 dairy processing plants to benchmark total energy usage (NRCan, 2001). It was determined that it was not possible to compare different plants directly because they stored milk on site for a short period of time, stored it at a distribution center, or transported it to retail outlets; therefore, they reported the total plant energy consumption both with or without cold storage data. In this study, we report our data similarly. Energy consumption for cold storage of the NRCan-surveyed plants ranged from a low of $0.0017 \mathrm{kWh} / \mathrm{L}$ to a high of $0.0843 \mathrm{kWh} / \mathrm{L}$. We report total plant energy consumption for the simulated plants with cold storage using the highest energy reported in the NRCan report, with a corresponding electricity index of $13.5 \mathrm{kWh} / \mathrm{m}^{2}$ per day $(1.25 \mathrm{kWh} /$ $\mathrm{ft}^{2}$ per day) assigned in the simulator for cold storage. We also report the total plant energy consumption on a cold storage-free basis, with an electricity index of 0.0 . The user can provide their own value of the electricity index for their particular method of cold storage. For cold storage of milk solely in the plant, values of the electricity index, with an average value of $0.840 \mathrm{kWh} /$ $\mathrm{m}^{2}$ per day $\left(0.078 \mathrm{kWh} / \mathrm{ft}^{2}\right.$ per day), found in ASHRAE (2007) for refrigerated warehouses, may be used in the simulator.

Ultrasonic case washers in the cold storage area consume significant amounts of water. It was assumed that $6,000 \mathrm{~L} / \mathrm{d}$ of water was used for case washing.

Cleaning-In-Place. Little quantitative information on CIP operations is available. This portion of the simulation model is an estimation of the CIP operation developed using the information provided in Eide et al. (2003) and from the dairy industry. Two CIP skids are used in our simulation, one for silos, tanks, and filling machines and the other for the pasteurizers. The cleaning sequences for the 2 skids are as follows:

Skid no. 1 (for milk silos, tanks, and filling machines)

1. Flush with warm water at $45^{\circ} \mathrm{C}$ for $10 \mathrm{~min}$.

2. Circulate the caustic cleaning solution at $75^{\circ} \mathrm{C}$ for $10 \mathrm{~min}$.

3. Rinse with water at $45^{\circ} \mathrm{C}$ for 5 min.

4. Disinfect with hot water at $95^{\circ} \mathrm{C}$ for $5 \mathrm{~min}$.

5. Gradual cooling with water at $25^{\circ} \mathrm{C}$ for $10 \mathrm{~min}$.

Skid no. 2 (for pasteurizers)

1. Flush with warm water at $45^{\circ} \mathrm{C}$ for $10 \mathrm{~min}$.

2. Circulate with caustic cleaning solution at $75^{\circ} \mathrm{C}$ for $30 \mathrm{~min}$.
3. Rinse with water at $45^{\circ} \mathrm{C}$ for 5 min.

4. Circulate with acidic cleaning solution at $70^{\circ} \mathrm{C}$ for $20 \mathrm{~min}$.

5. Rinse with water at $25^{\circ} \mathrm{C}$ for $15 \mathrm{~min}$.

6. Disinfect with hot water at $95^{\circ} \mathrm{C}$ for $15 \mathrm{~min}$.

A typical dairy has about 30 cleaning operations a day. To estimate the amount of material and energy used in the operation, each cleaning step was modeled as 1 cycle/d, $260 \mathrm{~d} / \mathrm{yr}$. The volumetric flow rate per vessel internal surface area was set at $12.7 \mathrm{~L} / \mathrm{m}^{2}$-min. Because the sizing of the equipment is calculated by the program, the amount of water, cleaning solution, steam, and auxiliary power used in the CIP operation can be predicted.

Wastewater Treatment. Wastewater generated from the CIP operations, the ultrasonic case washers, and sludge from the separator is sent to a wastewater treatment site for pretreatment before disposal. In the simulation, the wastewater (influent) stream combined with the recycled sludge stream was sent to the aeration tank for biooxidation of the organic material. The aeration tank was assumed to operate at an average hydraulic residence time of $6 \mathrm{~h}$ and an average sludge residence time of $23 \mathrm{~h}$ (Petrides et al., 1998). Aeration blowers maintained a minimum diffused air concentration of $20 \mathrm{mg} / \mathrm{L}$. The following stoichiometric reaction was assumed for the degradation of organic material in the waste stream (Santamarina, 1997):

$$
\begin{gathered}
1 \mathrm{~g} \text { of casein/lactose } \rightarrow 0.4 \mathrm{~g} \text { of biomass } \\
+0.3 \mathrm{~g} \text { of } \mathrm{H}_{2} \mathrm{O}+0.3 \mathrm{~g} \text { of } \mathrm{CO}_{2} .
\end{gathered}
$$

After biooxidation, the waste stream was sent to the clarifier where $99 \%$ of the biomass was removed and was concentrated to about $1 \% \mathrm{wt} / \mathrm{wt}$ solids content. The liquid effluent, which contained mostly water, was disposed of as aqueous waste. Seventy-five percent of the sludge stream was recycled back to the aeration tank. The rest was pumped to a belt filter press where it was thickened to $15 \%$ (wt/wt) solids content. The removed water, which contained small amounts of biomass and dissolved solids, was sent back to the aeration tank. The concentrated sludge stream was dewatered to a final solids concentration of $35 \%$ (wt/wt) using a sludge dryer and was disposed of as solid waste. The wastewater treatment operations are designed to accommodate process wastes only. The water used and wastes generated during milk tanker/truck cleaning and external cleaning of equipment and floors were not modeled in this study and would significantly increase the required plant capacity for wastewater treatment, as would other water use throughout the plant. 


\section{Process Data Entry}

Right clicking on an icon allows the user to enter operating data, procedure data, and equipment data. Operating data for a heat exchanger, for example, includes information such as temperature and pressure, the type of heating agent used (e.g., steam), and assumption of a value for the heat transfer coefficient. In the procedure data tab, the user indicates if the equipment is operated in a batch or continuous mode and the cycle time. Under the equipment data tab, information on the area available for heat transfer, and the type of heat exchanger (e.g., plate and frame vs. shell and tube) is indicated. The operating data tab allows the user to enter the characteristics of the milk, such as the flow rate, temperature, pressure, physical state, and composition by clicking on the stream arrows that connect 2 different unit operations.

\section{Cost Data}

The user may use the costs provided in the simulator or enter those from vendors, or both. In this study, cost data were based on the economic conditions of 2012 . Costs of milk, cleaning agents, and other materials were provided from the dairy industry or were estimated. Buildings and associated equipment such as refrigeration were estimated as a separate item. Sanitary construction was assumed for all equipment costs that were obtained from equipment manufacturers, members of the dairy industry, in-house cost data library, and from information found in Dalton et al. (2002), Persson (1987), Jacobs and Criner (1990), and Cole (2004). The installation costs were estimated by composite or Lang cost factors. The Lang factors, which were developed in a method for estimating the total installation costs for plant equipment, are multiplied by the basic equipment costs to account for engineering and construction, piping, electrical, and instrumentation (Ray and Sneesby, 1998; Peters et al., 2003).

The simulator generates reports such as the materials and streams report, an economic evaluation report, cash flow analysis report, itemized cost report, a throughput analysis report, an environmental impact report, an emissions report, an equipment report, a CIP Skid Report and an Input Data Report. Additional reports were added through the addition of Excel spreadsheets to collate the energy data generated from the simulation, such as that for electricity, steam, cooling water and chilled water used in each unit operation, to calculate the GHG emissions for each.

\section{Model Validation and Applications}

After creation of the model, data from a fluid milk processing plant in the United States and from the lit- erature were used to validate the model by comparison of the reported electrical and natural gas energy usages with the values predicted by the model. Data from the model and the literature were converted to SEC for ease of comparison.

The model was also used to demonstrate applications such as calculation of SEC, GHG emissions, and process economics for entire fluid milk processing plants of various sizes and to examine the effect of changes in one of the unit operations, such as the level of percentage regeneration in HTST pasteurization, or the use of total versus partial homogenization, on SEC and GHG. The effects of adjustments in the values of the nonprocess efficiencies, which were set to $25 \%$ for electrical usage (Peters et al. 2003) and 20\% for natural gas usage (Babcock \& Wilcox Company, 2005), on the total plant SEC and GHG emissions were also examined.

\section{RESULTS AND DISCUSSION}

To illustrate the base fluid milk process model (Figure 1), a simulation trial was conducted for the 40.0 million L/yr fluid milk processing plant. This model, as well as the other process models discussed in this study, was assumed to operate continuously. Milk was processed for $260 \mathrm{~d} / \mathrm{yr}, 16 \mathrm{~h} / \mathrm{d}$, with $8 \mathrm{~h} / \mathrm{d}$ dedicated to cleaning operations, similar in operation to many dairy plants in the United States. The simulation model applies from storage of the raw milk in silos to cold storage of the packaged product. It was assumed that only whole milk and $40 \%$ cream was processed throughout this study, although at the separation step, the operating conditions may be adjusted for a plant processing skim, 1, or $2 \%$ milk, or pasteurized cream products. The flow sheet may also be expanded through the addition of tanks or fermentation vessels for manufacture of chocolate milk products and products such as buttermilk. A regeneration of $94 \%$ was assumed in the regenerator section of the pasteurizer throughout, unless otherwise noted.

Upon completion of the simulation, an Excel (Microsoft Corp., Redmond, WA) spreadsheet was prepared to automatically extract energy usage data for each of the unit operations that compose the fluid milk process from the itemized cost report of SuperPro Designer (Table 2). The results are reported as obtained from the itemized cost report and were not rounded. Energy usage is reported in terms of the electricity to power the unit operations; steam used for pasteurization, standardization, cream pasteurization, CIP, and wastewater treatment; cooling water used in standardization; and chilled water used in the raw milk section and in milk and cream pasteurization to cool milk after it is pasteurized. These values are considered bare numbers, 
Table 2. Simulated annual utility usages for the unit operations in the base fluid milk processing plant with a production rate of 40.0 million L/yr

\begin{tabular}{|c|c|c|c|c|}
\hline Section & $\begin{array}{l}\text { Electricity } \\
(\mathrm{kWh} / \mathrm{yr})\end{array}$ & $\begin{array}{l}\text { Steam } \\
(\mathrm{t} / \mathrm{yr})\end{array}$ & $\begin{array}{l}\text { Cooling water } \\
\text { (t/yr) }\end{array}$ & $\begin{array}{c}\text { Chilled water } \\
(\mathrm{t} / \mathrm{yr})\end{array}$ \\
\hline Raw milk section & 1,633 & & & 6,137 \\
\hline Pasteurization & 1,095 & 372 & & 35,722 \\
\hline Homogenization & 219,065 & & & \\
\hline Standardization & 142,787 & 14 & 65,988 & \\
\hline Milk packaging & 563,861 & & & \\
\hline Cream pasteurization & 10 & 5 & & 4,825 \\
\hline Cream packaging & 15,622 & & & \\
\hline Cold storage & $2,308,800$ & & & \\
\hline CIP $^{1}$ & 6,842 & 1,310 & & \\
\hline Wastewater treatment & 18,067 & 164 & & \\
\hline Total & $3,277,822$ & 1,865 & 65,988 & 46,684 \\
\hline
\end{tabular}

as they are related to energy usage by the unit operations alone.

The annual utility usage data of Table 2 was converted to the primary sources, electrical energy, and natural gas to facilitate calculation of the GHG emissions for each unit operation as reported in Table 3. A $25 \%$ allowance (Peters et al., 2003) was first added to the electricity usage estimates of Table 2 to account for nonprocess utility requirements, such as the additional power losses in the electrical step-down transformers and distribution systems, instrumentation systems, plant communication systems, compressed air systems for air-driven controls or motors and blow molding, electrical heat tracing of piping exposed to cold external temperatures throughout the plant, building lighting, office plug loads, and office space conditioning. The allowance may be assigned from 10 to $25 \%$, depending on the efficiency of electrical processes in the plant.

The electrical energy used to generate the steam was taken into account using the conversion factor $0.55 \mathrm{kWh} / 1,000 \mathrm{~kg}$ of steam, provided by vendors, for an on-site natural gas steam-generating system. This factor may be adjusted depending on the user's natural gas system. A $20 \%$ allowance was added to the natural gas use to account for the inefficiency of the conversion of natural gas energy to steam energy in the boiler. This value was based on discussions with various boiler manufacturers and will vary depending on the design and operation of a specific boiler. Additional information on boiler efficiencies is found in Babcock \& Wilcox Co. (2005). The quantity of cooling water used from Table 2 was converted to kilowatt hours using the conversion factor $0.00011 \mathrm{~kW} / \mathrm{kg}$ of cooling tower water provided by a vendor for a cooling tower water system processing $9,720 \mathrm{~L}$ of water/min that required approximately $50 \mathrm{kWh}$ for the cooling tower fans and an additional $15 \mathrm{kWh}$ for the cooling water pumps and water treatment system. The quantity of chilled water used was first converted to energy units using the glycol energy-to-mass factor $(5.5046 \mathrm{kcal} / \mathrm{kg})$ from SuperPro. The result was converted to tons of refrigeration (TR), using the conversion factor $3,023 \mathrm{kcal} / \mathrm{TR}$. The result was multiplied by the factor $2 \mathrm{kWh} / \mathrm{TR}$ to report the quantity of chilled water in terms of electrical usage.

The GHG emissions associated with each of the unit operations are also shown in Table 3 and were calculated using the energy data for the unit operation and the conversion factors given in Deru and Torcellini (2007). The source emission factor for $\mathrm{CO}_{2 \mathrm{e}}$ used for electricity was 1.67 pounds $(0.758 \mathrm{~kg})$ of $\mathrm{CO}_{2 \mathrm{e}} / \mathrm{kWh}$. The source emission factor for $\mathrm{CO}_{2 \mathrm{e}}$ used for natural gas was 146.6 pounds of $\mathrm{CO}_{2 \mathrm{e}} /$ million BTU (0.06312 $\mathrm{kg}$ of $\left.\mathrm{CO}_{2 \mathrm{e}} / \mathrm{MJ}\right)$ of natural gas. The percentage contribution of each unit operation to total GHG emissions from the fluid milk process was calculated in 2 ways. In the first, a high value of the electricity index $\left(13.5 \mathrm{kWh} / \mathrm{m}^{2}\right.$ per day $)$ was used in the simulator for a plant with large energy usage attributed to cold storage (NRCan, 2001). In the second, the contribution of cold storage to total GHG emissions was omitted.

Greenhouse gas emissions were predicted by the simulation model as ranging between $90.8 \mathrm{~g}$ of $\mathrm{CO}_{2 \mathrm{e}} / \mathrm{kg}$ of milk, if cold storage with significant energy usage was assumed, and $36.2 \mathrm{~g}$ of $\mathrm{CO}_{2 \mathrm{e}} / \mathrm{kg}$ milk if cold storage was not considered in the model. Electricity usage for cold storage of milk contributed to $60.2 \%$ of GHG emissions for the simulated plant, followed by milk packaging $(14.7 \%)$, homogenization (5.7\%), and standardization (4.0\%). Greenhouse gas emissions from electricity usage totaled $81.0 \mathrm{~g}$ of $\mathrm{CO}_{2 \mathrm{e}} / \mathrm{kg}$ of milk. Steam required for CIP operations and milk pasteurization were the largest consumers of natural gas, contributing 7.8 and $4.9 \%$, respectively, to total GHG emissions. Most of the chilled water was used by the milk and cream pasteurization processes and was assumed to consume electricity. Greenhouse gas emissions from natural gas 
Table 3. Conversion of simulated annual utility usages of Table 2 to the primary energy sources electricity and natural gas and greenhouse gas (GHG) emissions for the unit operations in a base fluid milk processing plant with a production rate of 40.0 million L/yr

\begin{tabular}{|c|c|c|c|c|c|c|c|c|c|}
\hline Section & $\begin{array}{c}\text { Electricity } \\
+25 \% \\
(\mathrm{kWh} / \mathrm{yr})\end{array}$ & $\begin{array}{c}\text { Steam } \\
(\mathrm{kWh} / \mathrm{yr})\end{array}$ & $\begin{array}{c}\text { Natural } \\
\text { gas }+20 \% \\
(\mathrm{BTU} / \mathrm{yr})^{1}\end{array}$ & $\begin{array}{c}\text { Cooling } \\
\text { water } \\
(\mathrm{kWh} / \mathrm{yr})\end{array}$ & $\begin{array}{c}\text { Chilled } \\
\text { water } \\
(\mathrm{kWh} / \mathrm{yr})\end{array}$ & $\begin{array}{c}\mathrm{GHG}^{2} \\
\text { emissions } \\
(\mathrm{kg} \text { of } \\
\left.\mathrm{CO}_{2 \mathrm{e}} / \mathrm{yr}\right)^{3}\end{array}$ & $\begin{array}{c}\mathrm{GHG} \\
\text { (g of } \mathrm{CO}_{2 \mathrm{e}} / \\
\mathrm{kg} \text { of milk) }\end{array}$ & $\begin{array}{c}\% \text { GHG, } \\
\text { with cold } \\
\text { storage }\end{array}$ & $\begin{array}{c}\% \mathrm{GHG}, \\
\text { cold storage } \\
\text { free }\end{array}$ \\
\hline Raw milk section & 2,041 & & & & 22,352 & 18,500 & 0.5 & 0.5 & 1.3 \\
\hline Pasteurization & 1,369 & 205 & $1,180,638,720$ & & 130,107 & 178,600 & 4.5 & 4.9 & 12.3 \\
\hline Homogenization & 273,831 & & & & & 207,900 & 5.2 & 5.7 & 14.3 \\
\hline Standardization & 178,484 & 8 & $44,432,640$ & 7,272 & & 144,000 & 3.6 & 4.0 & 9.9 \\
\hline Milk packaging & 704,826 & & & & & 535,000 & 13.3 & 14.7 & 36.9 \\
\hline Cream pasteurization & 13 & 3 & $15,868,800$ & & 17,574 & 14,400 & 0.4 & 0.4 & 1.0 \\
\hline Cream packaging & 19,578 & & & & & 14,900 & 0.4 & 0.4 & 1.0 \\
\hline Cold storage $^{4}$ & $2,886,000$ & & & & & $2,190,700$ & 54.8 & 60.2 & \\
\hline CIP $^{5}$ & 8,553 & 722 & $4,157,625.600$ & & & 284,100 & 7.1 & 7.8 & 19.6 \\
\hline Wastewater treatment & 22,584 & 90 & $520,496,640$ & & & 51,900 & 1.3 & 1.4 & 3.6 \\
\hline
\end{tabular}

${ }^{1} \mathrm{BTU}=$ British thermal unit. Equivalent values in megajoules per year are given in Table 4.

${ }^{2} \mathrm{GHG}=$ greenhouse gas.

${ }^{3} \mathrm{CO}_{2 \mathrm{e}}=\mathrm{CO}_{2}$ equivalents

${ }^{4} \mathrm{An}$ electricity index of $13.5 \mathrm{kWh} / \mathrm{m}^{2}$ per day was used in the simulator for cold storage on site and in a distribution center. For on-site cold storage, $0.840 \mathrm{kWh} / \mathrm{m}^{2}$ per day (ASHRAE, 2007) may be used.

${ }^{5}$ Clean-in-place.

Table 4. Energy and specific energy consumption (SEC) associated with electricity, natural gas, cooling water, and chilled water use for each unit operation in the fluid milk processing plant with a production rate of 40.0 million $\mathrm{L} / \mathrm{yr}$

\begin{tabular}{|c|c|c|c|c|c|c|c|c|}
\hline Section & $\begin{array}{l}\text { Electricity } \\
(\mathrm{MJ} / \mathrm{yr})\end{array}$ & $\begin{array}{c}\text { Steam, } \\
\text { electrical } \\
\text { (MJ/yr) }\end{array}$ & $\begin{array}{c}\text { Steam, } \\
\text { natural gas } \\
(\mathrm{MJ} / \mathrm{yr})\end{array}$ & $\begin{array}{l}\text { Cooling } \\
\text { water } \\
(\mathrm{MJ} / \mathrm{yr})\end{array}$ & $\begin{array}{l}\text { Chilled } \\
\text { water } \\
(\mathrm{MJ} / \mathrm{yr})\end{array}$ & $\begin{array}{l}\text { Energy } \\
(\mathrm{MJ} / \mathrm{yr})\end{array}$ & $\begin{array}{c}\text { SEC } \\
(\mathrm{MJ} / \mathrm{kg})\end{array}$ & Energy use ${ }^{1}(\%)$ \\
\hline Raw milk section & 7,350 & & & & 80,500 & 87,850 & 0.002 & $0.4(0.8)$ \\
\hline Pasteurization & 4,930 & 700 & $1,245,600$ & & 468,400 & $1,719,630$ & 0.04 & $7.9(15.3)$ \\
\hline Homogenization & 985,800 & & & & & 985,800 & 0.03 & $4.6(8.8)$ \\
\hline Standardization & 642,500 & 30 & 46,900 & 26,200 & & 715,630 & 0.03 & $3.3(6.4)$ \\
\hline Milk packaging & $2,537,400$ & & & & & $2,537,400$ & 0.06 & $11.7(22.6)$ \\
\hline Cream pasteurization & 50 & 10 & 16,700 & & 63,300 & 80,060 & 0.00 & $0.4(0.7)$ \\
\hline Cream packaging & 70,500 & & & & & 70,500 & 0.00 & $0.3(0.6)$ \\
\hline Cold storage $^{2}$ & $10,389,600$ & & & & & $10,389,600$ & 0.26 & $48.0(0)$ \\
\hline $\mathrm{CIP}^{3}$ & 30,800 & 2,600 & $4,386,500$ & & & $4,419,900$ & 0.11 & $20.4(39.3)$ \\
\hline Wastewater treatment & 81,300 & 330 & 549,200 & & & 630,830 & 0.02 & $2.9(5.6)$ \\
\hline Total energy & $14,750,230$ & 3,670 & $6,244,900$ & 26,200 & 612,200 & $21,637,100$ & & \\
\hline SEC & 0.37 & 0.00 & 0.16 & 0.00 & 0.02 & 0.54 & 0.54 & \\
\hline
\end{tabular}

Values in parentheses are on a cold-storage free basis.

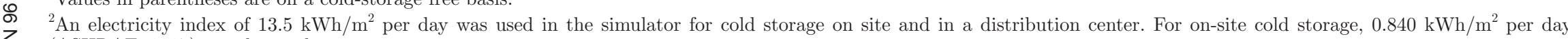
Z. (ASHRAE, 2007) may be used.

or ${ }^{3}$ Clean-in-place. 
usage were predicted as $9.8 \mathrm{~g}$ of $\mathrm{CO}_{2 \mathrm{e}} / \mathrm{kg}$ of milk. The simulation was also repeated using the average value of the electricity index: $0.840 \mathrm{kWh} / \mathrm{m}^{2}$ per day (ASHRAE, 2007) for a refrigerated warehouse. The GHG emissions from cold storage were then $4.7 \mathrm{~g}$ of $\mathrm{CO}_{2 \mathrm{e}} / \mathrm{kg}$ of milk, with a percentage contribution to total GHG emissions of $11.8 \%$.

The energy data reported in Table 3 were also used to calculate the energy usage and the SEC of each unit operation, and the total SEC of the process as shown in Table 4. In addition to the GHG emissions calculated in Table 3, SEC, calculated for each unit operation, is useful for comparing the energy usage of the unit operations and for comparing the energy efficiencies across different fluid milk processing plants ( $\mathrm{Xu}$ and Flapper, 2009). In facilities with a high cold storage energy usage, energy consumption decreases in the following order: cold storage, CIP, milk packaging, and milk pasteurization. If cold storage is not considered, CIP operations are the most energy intensive. For a refrigerated warehouse with an electricity index of $0.840 \mathrm{kWh} /$ $\mathrm{m}^{2}$ per day (ASHRAE, 2007), the percentage energy contribution of cold storage is then $7.7 \%$, with CIP operations the most energy intensive unit operation.

The economic evaluation report provides a summary of the capital costs of the equipment, the operating costs, and unit operating costs for conducting an economic analysis of the process. The yearly operating costs for the base 40.0 million L/yr plant are $\$ 24,352,000$. Table 5 provides more detailed information on the costs of utilities, raw materials, labor, and waste disposal costs. The utilities do not include the capital costs associated with their generation. Capital depreciation is listed separately. The other facility-dependent costs include maintenance, which is $3 \%$ of capital costs; insurance, which is $0.8 \%$ of capital costs; and factory expenses, which are $0.75 \%$ of capital costs.

\section{Model Validation}

Model validation is necessary to ensure its accuracy for each section of a process or over the entire process. Dairy processing plants are metered to record data on electricity use, fuel use, water use, and wastewater. This information can be used to benchmark the entire plant, but not the individual processes. Xu and Flapper (2009) analyzed energy data of plants both nationally and internationally and found that the SEC of individual plants ranged from 0.2 to $12.6 \mathrm{MJ} / \mathrm{kg}$ of fluid milk produced. Plants with low SEC are more energy efficient than plants with large SEC. For plants in the United States, the US Department of Energy Industrial Assessment Report (US DOE, 2010) reported values of SEC ranging from 0.2 to $6.0 \mathrm{MJ} / \mathrm{kg}$. In this study, SEC was $0.54 \mathrm{MJ} / \mathrm{kg}$ of milk (Table 4) for the base fluid milk plant processing 40.0 million L/yr, which is in the lower end of the range of SEC reported for plants in the United States. If cold storage is not considered in the calculation of SEC, then SEC is as low as 0.27.

The performance of the simulation model in predicting benchmark energy usage data at various stages of milk processing reported by NRCan (2001) was also examined. Benchmarking values for the processes in the NRCan study were established from the 10th percentile of the plants in a survey sample having the lowest values of SEC for milk receiving, separation, homogenization/pasteurization, filling, and CIP. The following SEC (in MJ $/ \mathrm{kg}$ ) were reported: 0.018 (milk receiving), 0.018 (separation), 0.189 (homogenization/pasteurization), 0.036 (filling/packaging), and 0.108 (CIP). An overall SEC of $0.1183 \mathrm{kWh} / \mathrm{L}$ of milk $(0.4183 \mathrm{MJ} / \mathrm{kg}$ of milk) was reported for the entire plant. For comparison, the SEC values (Table 4) calculated by the simulation model (in $\mathrm{MJ} / \mathrm{kg}$ ) were 0.002 (milk receiving), 0.017 (separation), 0.07 (homogenization/pasteurization), 0.06 (filling/packaging), and 0.11 (CIP), respectively, with an overall SEC of $0.27 \mathrm{MJ} / \mathrm{kg}$, excluding cold storage. All of the simulated values for the individual processes were within the ranges reported for the 17 plants surveyed in the Canadian study. The NRCan (2001) reported that the range of SEC for pasteurization/homogenization for the 17 plants ranged from 0.0691 to $0.9882 \mathrm{MJ} / \mathrm{kg}$. The value of SEC from this study $(0.07 \mathrm{MJ} / \mathrm{kg})$ is in agreement with the lowest value in the range for pasteurization/homogenization of the NRCan study and below the 10th percentile of values. The large range of SEC values for pasteurization/ homogenization reported by NRCan reflect that steam was generated not only by natural gas in the 17 plants that were sampled, but also by other fuel sources such as bunker carbon, light fuel oil, and propane. In addition, boiler efficiencies and the percentage regeneration used in the regeneration section of the pasteurizers was not reported and would be expected to vary from plant to plant. Greenhouse gas emissions were not reported in the NRCan (2001) report.

The performance of the process simulation model in predicting energy consumption data (Table 6) for several production scenarios in pasteurized milk production (Nicol et al., 2005) was also determined. The assumed pasteurization temperature and holding time were not reported. Also, the reported energy associated with CIP operations was approximately $80 \%$ lower than that reported by NRCan (2001), Xu and Flapper (2009), and the Innovation Center for US Dairy (Tomasula and Nutter, 2011) and was not simulated.

The pasteurization/homogenization scenarios were simulated using the same production rate of $24,000 \mathrm{~L}$ of 
Table 5. Annual operating costs for the base fluid milk plant producing 40.0 million L/yr of whole milk

\begin{tabular}{|c|c|c|c|}
\hline Item & Unit cost $(\$)$ & Amount/yr & $\$ / y r$ \\
\hline \multicolumn{4}{|l|}{ Raw materials } \\
\hline Milk & 0.36 & $39,998,961 \mathrm{~kg}$ & $14,417,860.68$ \\
\hline Oxygen & 0.00 & $500 \mathrm{~kg}$ & 0.00 \\
\hline Resin for gallon jugs & 2.54 & $597,735 \mathrm{~kg}$ & $1,515,448.47$ \\
\hline Paper pint containers for cream & 0.02 & $1,566,153$ & $31,323.06$ \\
\hline Water & & $10,751,254 \mathrm{~kg}$ & $3,795.19$ \\
\hline Water $(\mathrm{CIP})^{1}$ & 0.00 & $8,697,016 \mathrm{~kg}$ & $3,070.05$ \\
\hline Wastewater treatment & & $502,499 \mathrm{~kg}$ & 177.38 \\
\hline Cold storage & & $1,551,739 \mathrm{~kg}$ & 547.76 \\
\hline Air & & $1,339,510 \mathrm{~kg}$ & 0.00 \\
\hline Caustic cleaner & 0.01 & $1,687,072 \mathrm{~kg}$ & $22,905.32$ \\
\hline Acid cleaner & 0.05 & $587,822 \mathrm{~kg}$ & $30,374.05$ \\
\hline Total raw materials & & & $16,021,706.77$ \\
\hline Labor & 40.00 & $124,800 \mathrm{~h}$ & $4,992,000.00$ \\
\hline \multicolumn{4}{|l|}{ Waste treatment disposal } \\
\hline \multicolumn{4}{|l|}{ Waste costs } \\
\hline Solid waste & 0.05 & $85,746 \mathrm{~kg}$ & \\
\hline Aqueous waste & & $12,826,199 \mathrm{~kg}$ & \\
\hline Total waste treatment & & & $4,287.00$ \\
\hline \multicolumn{4}{|l|}{ Utilities } \\
\hline Electricity & 0.09 & $3,277,823 \mathrm{kWh}$ & $196,669.38$ \\
\hline Heat transfer agents & & $114,537,482 \mathrm{~kg}$ & $67,595.00$ \\
\hline Steam & 12.00 & $1,865 \mathrm{t}$ & $22,386.00$ \\
\hline Cooling water & 0.07 & $65,988 \mathrm{t}$ & $4,619.19$ \\
\hline Glycol & 0.35 & $46,684 \mathrm{t}$ & $16,339.27$ \\
\hline Total utilities & & & $240,014.00$ \\
\hline Depreciation & & & $2,127,000.00$ \\
\hline Other facility-dependent costs & & & $968,000.00$ \\
\hline Total & & & $24,352,000.00$ \\
\hline
\end{tabular}

milk/h, $16 \mathrm{~h}$ of production/d, with $8 \mathrm{~h}$ of cleaning, and a boiler efficiency of $85 \%$. The pasteurization temperature of $77^{\circ} \mathrm{C}$ and holding time of $22 \mathrm{~s}$ used throughout our study was assumed for the simulations. The flow sheet for the simulation process model with partial homogenization is shown in Figure 2.

Overall, good agreement between the plant energy values (Nicol et al., 2005) and those predicted by the model for the thermal phases of pasteurization and chilled water production were noted for all processing scenarios, correctly showing the effect that increasing percentage regeneration has on reducing thermal energy, with an average absolute deviation of $1.9 \mathrm{MJ} / \mathrm{kL}$, and chilled water use, with an average absolute deviation of $4.3 \mathrm{MJ} / \mathrm{kL}$. The predicted values of electricity were also in good agreement, with an average absolute deviation of $1.2 \mathrm{MJ} / \mathrm{L}$. The reduction in electricity usage during homogenization was also correctly predicted when the partial homogenizer replaced the homogenizer, with an average absolute deviation of $4.1 \mathrm{MJ} / \mathrm{kL}$.

In a final test of the simulator, utility data from a large dairy processing plant were used to calculate the plant SEC for electrical and natural gas usage and compared with that of the simulator. Using data for 4 wk of a run producing $16.51 \times 10^{6} \mathrm{~kg}$ of whole milk, the electrical usage of the plant was $1.418 \times 10^{6} \mathrm{kWh}$ and the natural gas usage was $1.721 \times 10^{6}$ MJ $(1.632$ $\left.\times 10^{9} \mathrm{BTU}\right)$. The plant was not in operation for $2 \mathrm{~d}$ of each week. The calculated SEC for electricity was $0.31 \mathrm{MJ} / \mathrm{kg}$ and that for natural gas was $0.17 \mathrm{MJ} / \mathrm{kg}$, with a total SEC for the plant of $0.48 \mathrm{MJ} / \mathrm{kg}$, which is considered an efficient plant by the criteria of $\mathrm{Xu}$ and Flapper (2009). The SEC for electricity of the plant $(0.31 \mathrm{MJ} / \mathrm{kg})$ was lower than that predicted by the simulator $(0.38 \mathrm{MJ} / \mathrm{kg})$, which increases the predicted process energy by a $25 \%$ allowance (Peters et al., 2003) to account for miscellaneous electrical plant energy. If a $10 \%$ allowance is used in the simulator instead, then good agreement is obtained with the plant data. The need for the lower factor is an indication that the plant initiated energy-saving measures. The SEC for natural gas usage predicted by the simulator was $0.09 \mathrm{MJ} / \mathrm{kg}$, whereas that of the plant was $0.17 \mathrm{MJ} / \mathrm{kg}$. Natural gas is most likely used for other plant operations to heat water not accounted for in the simulator, such as in the milk receiving area, and for cleaning milk tankers and the surrounding area and the floors of the plant.

The fluid milk model also predicts the amount of water used in each unit operation, giving users the option of designing strategies that minimize water use in processing. Unfortunately, process water data was not available in the literature or from industry sources to 
validate the performance of the model. Water usage data for entire dairy plants was available, though, and can range from $1.02 \mathrm{~L}$ of water/L of milk processed to approximately $3 \mathrm{~L}$ of water/L of milk processed (personal communications with dairy plant managers). For a plant processing 40.0 million L/yr of milk, the simulation model predicted that $0.3 \mathrm{~L}$ of water was used for CIP and case washing per liter of milk processed. Including the utility water used in cooling and chilling operations (Table 2), which totals $112,672,000 \mathrm{~kg}$ and is recovered and reused in the plant, and adding about $5 \%$ make-up water to account for losses during the recovery/reuse operations, would only increase simulatorpredicted usage of water to $0.4 \mathrm{~L}$ of water/L of milk processed. The simulation model currently does not account for cleaning of milk tankers or external equipment and floor cleaning that occurs in a dairy plant. In future iterations of the simulation model, either unit operation models may be developed to represent these washing and cleaning activities or a factor could be added to the process water usage calculated by the simulator to account for washing and cleaning. The heavy use of water indicates several opportunities for development of best practices for decreasing water use for cleaning and washing throughout the plant. Several water efficiency measures for dairy processing plants are discussed in Brush et al. (2011).

\section{Model Applications}

For the fluid milk process, the prediction of SEC, GHG emissions, and process economics is affected by the flow rate of the process and the electrical and fuel energy used in the process. The electrical and fuel energy usage depends on the energy used to directly process milk and the non-process-related activities encountered in a milk processing plant. The use of the simulator for prediction of SEC, GHG emissions, and process economics is shown in this section and demonstrates the flexibility of the simulator for assisting processors in benchmarking their current operations and then improving the energy efficiency of their plants.

Simulation of Small, Medium, and Large Dairy Plants. Dairy plant models were constructed for a medium (113.6 million L/yr) and a large (227.1 million L/yr) plant to determine if plant size affected energy usage in terms of SEC, GHG emissions, and processing costs, compared with the 40.0 million L/ yr base plant. In the United States, plants producing $<75.7$ million L of milk/yr are considered small plants, plants producing between 75.7 and 151.4 million L of milk/yr are considered medium-sized plants, and plants producing $>151.4$ million $\mathrm{L}$ of milk/yr are considered large plants. The simulations apply from storage of the 
Table 7. Allocation of electricity and fuel to total energy and total specific energy consumption (SEC) for 3 facilities $^{1}$

\begin{tabular}{|c|c|c|c|c|c|c|}
\hline Facility & $\begin{array}{l}\text { Electricity } \\
(\mathrm{kWh} / \mathrm{yr})\end{array}$ & $\begin{array}{l}\text { SEC for electricity } \\
(\mathrm{MJ} / \mathrm{kg})\end{array}$ & $\begin{array}{l}\text { Natural gas } \\
(\mathrm{MJ} / \mathrm{yr})\end{array}$ & $\begin{array}{c}\text { SEC, } \\
\text { natural gas } \\
(\mathrm{MJ} / \mathrm{kg})\end{array}$ & $\begin{array}{l}\text { Total energy } \\
(\mathrm{MJ} / \mathrm{yr})\end{array}$ & $\begin{array}{c}\text { Total SEC } \\
(\mathrm{MJ} / \mathrm{kg})\end{array}$ \\
\hline $40.0 \times 10^{6} \mathrm{~L} / \mathrm{yr}$ & $\begin{array}{c}4,275,000 \\
(1,390,000)\end{array}$ & $0.38(0.13)$ & $6,245,000$ & 0.16 & $\begin{array}{c}21,637,000 \\
(11,248,000)\end{array}$ & $\begin{array}{c}0.54 \\
(0.28)\end{array}$ \\
\hline $113.6 \times 10^{6} \mathrm{~L} / \mathrm{yr}$ & $\begin{array}{l}12,060,000 \\
(3,935,000)\end{array}$ & $0.38(0.13)$ & $14,040,000$ & 0.12 & $\begin{array}{c}57,457,000 \\
(28,207,000)\end{array}$ & $\begin{array}{c}0.51 \\
(0.25)\end{array}$ \\
\hline $227.1 \times 10^{6} \mathrm{~L} / \mathrm{yr}$ & $\begin{array}{l}24,115,000 \\
(7,865,000)\end{array}$ & $0.38(0.13)$ & $24,461,000$ & 0.11 & $\begin{array}{l}111,278,000 \\
(52,778,000)\end{array}$ & $\begin{array}{c}0.49 \\
(0.23)\end{array}$ \\
\hline
\end{tabular}

${ }^{1}$ Evaluated with cold storage and on a cold storage-free basis (the latter values in parentheses).

${ }^{2}$ An electricity index of $13.5 \mathrm{kWh} / \mathrm{m}^{2}$ per day was used in the simulator for cold storage on site and in a distribution center. For on-site cold storage, $0.840 \mathrm{kWh} / \mathrm{m}^{2}$ per day (ASHRAE, 2007) may be used.

milk in silos to cold storage of the packaged product at the plant.

The predicted annual total energy $(\mathrm{MJ} / \mathrm{yr})$ for the small, medium, and large facilities, with the individual contributions from process electricity $(\mathrm{kWh} / \mathrm{yr})$ and natural gas usage $(\mathrm{MJ} / \mathrm{yr})$ are reported in Table 7 . The corresponding total energy and electricity for plants on a cold storage-free basis are also reported. The data were converted to SEC to facilitate comparison of the plants.

The values of the total SEC show a small decrease as plant size was increased. With increasing plant size from 40.0 to 113.6 million L/yr, SEC decreased by $6 \%$. The SEC decreased only $4 \%$ when plant size was increased from 113.6 to 227.1 million L/yr, but decreased by $9 \%$ when plant size increased from 40.0 million to 113.6 million L/yr, showing a small improvement in energy efficiency for plants of larger size. Whereas the SEC for the electricity-dependent unit operations of all plants was constant at 0.38 , the SEC for the natural gas-dependent operations, which are mainly CIP operations and milk and cream pasteurization, decreased by $0.16,0.12$, and 0.11 , respectively, with increasing plant size, indicating a reduced use of steam as plant size became larger.

To investigate which operation had reduced energy usage as plant size was increased, SEC was recalculated eliminating CIP in the calculation. The SEC for the milk and cream pasteurization processes for all plants was 0.033 , indicating that SEC for CIP operations decreased with increasing plant size and that the CIP operation was most efficient for the largest plant. In the simulation models, the volumetric flow rates for the cleaning solutions and rinse water in each plant were assumed to be the same. The amount of water used is proportional to the volumetric flow rate/internal surface area of the equipment. As the plants increase in size, the volume of the equipment that is cleaned increases but there is a smaller rate of change in the internal surface area as the volume increases. Thus, the amount of water or cleaning solution needed decreases as plant size increases.

Using the energy consumption data of Table 7 , the GHG emissions for the 113.6 million and 227.1 million $\mathrm{L} / \mathrm{yr}$ plants were calculated and compared with those for the 40.0 million L/yr plant, as shown in Table 8. For all plants, the GHG emissions associated with the unit operations are the same as those reported for the 40.0 million L/yr plant shown in Table 3, with the exception of the value reported for CIP operations (data not shown). The carbon footprint of milk decreased slightly with increasing plant size, from a value of $91.0 \mathrm{~g}$ of $\mathrm{CO}_{2 \mathrm{e}} / \mathrm{kg}$ of milk for the smallest plant to a value of 87.5 $\mathrm{g}$ of $\mathrm{CO}_{2 \mathrm{e}} / \mathrm{kg}$ of milk for the larger plant, reflecting the impact of the more efficient use of natural gas energy in CIP operations as plant size increased (Table 7). The values for the carbon footprint of milk are in good agreement with the average value of $96 \mathrm{~g}$ of $\mathrm{CO}_{2 \mathrm{e}} / \mathrm{kg}$ of packaged milk (Tan et al., 2011; Thoma et al., 2012) for milk processing and packaging, demonstrating the predictive ability of the simulator. Recalculating the carbon footprint of milk by neglecting on-site cold storage shows that the plant total GHG emissions decrease by about $60 \%$ for all plants to a value of $36.2 \mathrm{~g}$ of $\mathrm{CO}_{2 \mathrm{e}} /$ $\mathrm{kg}$ of milk for the smallest plant.

A summary of the economic analysis for the plants generated by the economic evaluation report of the software is shown in Table 9. The capital costs include all costs related to the equipment and the processing plant facility but not additional facilities that might be on site. Other costs such as start-up costs and costs of capital are not included. The annual operating costs are the sum of the costs of utilities, waste treatment, raw materials, labor, and other facility-dependent costs. Costs related to transportation, advertising, failed product disposal, and laboratory analyses, were not included in this analysis. The unit production costs are the sum of the operating costs and capital depreciation divided by the filled gallon entities. 
Table 8. Greenhouse gas (GHG) emissions for 3 facilities with cold storage and on a cold storage-free basis ${ }^{1,2}$

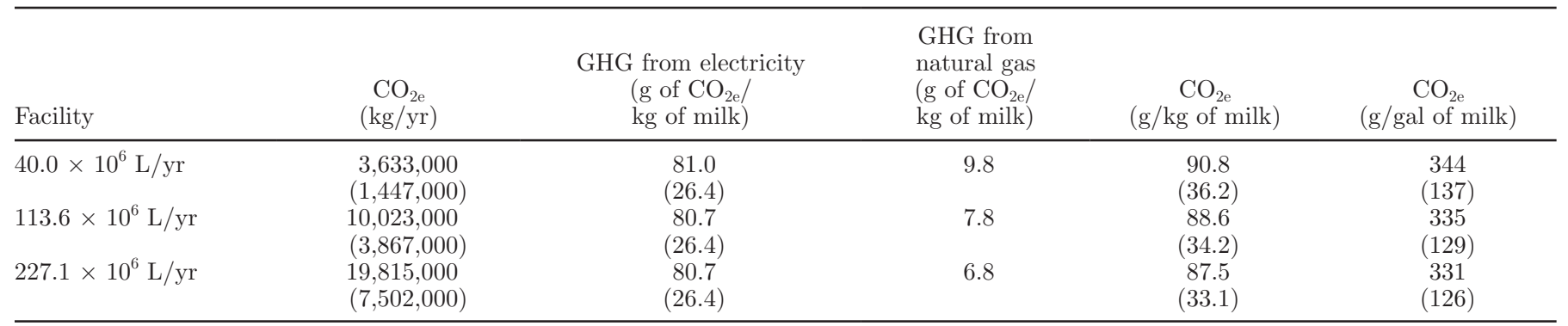

${ }^{1} \mathrm{CO}_{2 \mathrm{e}}=\mathrm{CO}_{2}$ equivalent; gal $=$ gallon of whole milk $=3.785 \mathrm{~L}$ of whole milk.

${ }^{2}$ Values in parentheses are on a cold storage-free basis.

The unit production costs for the 40.0 million L/ yr plant (\$2.36/entity) are greater than those for the 113.6 million L/yr (\$2.02/entity) and 227.1 million L/ yr (\$1.91) plants. Economy of scale effects are demonstrated with decreased labor, equipment, and facility costs as a percentage of plant capacity. However, as shown earlier in Tables 7 and 8, the scale of the plant has little effect on energy usage or the carbon footprint of milk per kilogram of milk produced.

Effect of Level of Percentage Regeneration. The level of percentage regeneration is known to affect the amount of the heating and cooling energy associated with pasteurization that is saved. To demonstrate its effects, the 40.0 million $\mathrm{L} / \mathrm{yr}$ plant was simulated with successive changes in the levels of percentage regeneration to $90,92,94,95$, and $96 \%$. The results are reported in Table 10. Increasing levels of percentage regeneration showed a small, insignificant decrease in the amount of electricity associated with boiler production of steam. However, natural gas use in pasteurization decreased from $1,940,000$ to $807,000 \mathrm{MJ} / \mathrm{yr}$ as percentage regeneration was increased from 90 to $96 \%$. Chilled water use decreased from 709,000 to 317,000 $\mathrm{MJ} / \mathrm{yr}$ over the same increase in percentage regenera- tion. Overall, the total energy used in pasteurization showed a $57 \%$ decrease in energy use from 2,654,000 to $1,129,000 \mathrm{MJ} / \mathrm{yr}$, with SEC decreasing from 0.07 to $0.03 \mathrm{MJ} / \mathrm{kg}$ and the carbon footprint of milk from 6.8 to $3.0 \mathrm{~g}$ of $\mathrm{CO}_{2 \mathrm{e}} / \mathrm{kg}$ of milk.

As shown earlier, the model was used to predict the thermal and electrical energy when partial homogenization is used (Table 6). Even though partial homogenization lowers electricity use of the homogenization step by $82 \%$, steam consumption increases by $77 \%$ because milk enters the second regeneration section at lower temperature. Full homogenization heats the milk stream to a higher temperature when conventional milk processing is used. In comparison with the 40.0 million $\mathrm{L} / \mathrm{yr}$ base plant with full homogenization, the decrease in electricity with partial homogenization results in a $5.4 \%$ decrease in the carbon footprint of milk from 90.8 (Table 3) to $87.1 \mathrm{~g}$ of $\mathrm{CO}_{2 \mathrm{e}} / \mathrm{kg}$ of milk. Utility costs are also reduced with partial homogenization. The costs of utilities with full homogenization are $\$ 240,014 / \mathrm{yr}$ and are $\$ 231,813 /$ yr with partial homogenization.

Alternatives to HTST Pasteurization. Although increasing the percentage regeneration of the pasteurizer from 90 to $96 \%$ resulted in significant reductions

Table 9. Summary of economic analysis for the production of fluid milk for small, medium, and large processing plants

\begin{tabular}{lcrr} 
& & Processing plant & \\
\cline { 2 - 4 } Item & 40.0 million L/yr & 113.6 million L/yr & 227.1 million L/yr \\
\hline Filled gallon entities (no.) & $10,305,783$ & $29,161,110$ & $58,322,220$ \\
Capital costs $(\$)$ & $21,266,000.00$ & $28,124,000.00$ & $39,674,000.00$ \\
Equipment & $5,633,000.00$ & $9,062,000.00$ & $14,837,000.00$ \\
Operating costs ${ }^{1}(\$)$ & $22,226,000.00$ & $56,230,000.00$ & $107,237,000.00$ \\
Utilities & $240,000.00$ & $664,000.00$ & $1,316,000.00$ \\
Waste treatment & $4,000.00$ & $45,288,000.00$ & $24,000.00$ \\
Raw materials & $16,022,000.00$ & $8,986,000.00$ & $90,530,000.00$ \\
Labor & $4,992,000.00$ & $1,280,000.00$ & $13,562,000.00$ \\
Other facility & $968,000.00$ & $2,812,000.00$ & $1,805,000.00$ \\
Capital depreciation $(\$)$ & $2,127,000.00$ & $2.02 / \mathrm{MP}$ entity & $3,967,000.00$ \\
Unit production costs $(\$)$ & $2.36 / \mathrm{MP}$ entity ${ }^{2}$ & $1.91 / \mathrm{MP}$ entity \\
\hline
\end{tabular}

${ }^{1}$ Operating costs do not include depreciation. Depreciation is reported as a separate item.

${ }^{2} \mathrm{MP}$ entity $=1$ gallon of whole milk packaged $=3.785 \mathrm{~L}$ of whole milk packaged. 
Table 10. Effect of percentage regeneration $(\% \mathrm{R})$ on electricity associated with boiler producton of steam, fuel, chilled water, total energy use, specific energy consumption (SEC), and greenhouse gas (GHG) emissions in pasteurization for a 40.0 million L/yr plant

\begin{tabular}{|c|c|c|c|c|c|}
\hline \multirow[b]{2}{*}{ Item } & \multicolumn{5}{|c|}{$\% \mathrm{R}$} \\
\hline & $90 \%$ & $92 \%$ & $94 \%$ & $95 \%$ & $96 \%$ \\
\hline Natural gas (MJ/yr) & $1,940,000$ & $1,560,000$ & $1,245,600$ & 998,000 & 807,000 \\
\hline Chilled water (MJ/yr) & 709,000 & 577,000 & 468,300 & 382,000 & 317,000 \\
\hline Total energy (MJ/yr) & $2,650,000$ & $2,140,000$ & $1,714,600$ & $1,380,000$ & $1,130,000$ \\
\hline $\mathrm{SEC}(\mathrm{MJ} / \mathrm{kg})$ & 0.07 & 0.05 & 0.04 & 0.04 & 0.03 \\
\hline
\end{tabular}

${ }^{1} \mathrm{CO}_{2 \mathrm{e}}=\mathrm{CO}_{2}$ equivalent.

in energy use and a $56 \%$ reduction in $\mathrm{g}$ of $\mathrm{CO}_{2 \mathrm{e}} / \mathrm{kg}$ of milk (Table 10), HTST pasteurized milk requires cold storage, which has been shown through the simulation studies here to contribute up to $60.8 \%$ to total plant GHG emissions (Table 3 ) and $49.3 \%$ to total energy use of the process (Table 4). Milk pasteurized using alternative pasteurization methods, described in detail in Tomasula and Nutter (2011), such as UHT milk pasteurization (Datta et al., 2002), does not require cold storage if packaged aseptically. Although UHT pasteurization consumes more energy than HTST pasteurization (Juriaanse, 1999), a net energy savings would be realized, as electrical energy to power cold storage at the plant or at distribution and retail sites would be eliminated (Chandarana et al., 1984).

Microfiltration (Hoffman et al., 2006; Kulozik, 2007; Tomasula et al., 2011) is another alternative pasteurization method that is used as a unit operation before HTST pasteurization to remove the somatic cells, microflora, and pathogens, if present, in milk. Milk microfiltration is currently used in several countries and requires electrical energy to operate. Microfiltration equipment must also be cleaned intensely to remove a milk fouling layer if present and to prevent microbial growth on the membrane. The process simulator would allow processors to evaluate the feasibility of installation of microfiltration units into existing fluid milk processing lines to evaluate GHG emissions, increases in energy usage, if any, water use, and costs.

Other alternative pasteurization methods such as pulsed electric fields and high-pressure processing (Datta et al., 2005; Toepfl et al., 2006) require lower pasteurization temperatures than HTST pasteurization. At the current time, these methods are still under investigation and not yet scalable for use in large fluid milk processing facilities. The process simulator presented in this study will be a useful tool for investigating the feasibility of these and other nonthermal methods in a fluid milk processing line.

The GHG emissions, energy use, and costs associated with aseptic packaging may also be evaluated using the simulator. However, a model for aseptic packaging needs to be developed. Alternative processing methods also may require new or significant modifications of CIP procedures now used with HTST pasteurization processing, which may be explored with modifications to the simulator.

Impact of Nonprocess Efficiencies. The simulator assumes a boiler efficiency of $80 \%$, which may be adjusted to determine the effect of boiler efficiency on the total energy used to process milk. A factor of $25 \%$, which may also be adjusted, was also added to the simulated electrical bare energies of the unit operations to account for nonprocess electrical requirements in the plant. Adjustment of these factors in the simulator would allow a processor to determine their effect on SEC and GHG emissions as well as the cost savings (not shown) if best practices are implemented to reduce energy consumption.

Table 11 shows the impact of various combinations of boiler efficiencies for steam production and nonprocess electrical requirements compared with the factors used in the simulator. If boiler efficiency is held constant at $80 \%$ (20\% factor) and the electricity factor is varied from 0 to $25 \%$, total energy consumption of the plant increases from 18,138,000 to $21,637,000 \mathrm{MJ} / \mathrm{kg}$ of milk (an increase of 19\%). The carbon footprint of milk then increases from 74 to $91 \mathrm{~g}$ of $\mathrm{CO}_{2 \mathrm{e}} / \mathrm{kg}$ of milk, an increase of $23 \%$ and an indication that reducing nonprocess electrical energy usage through implementation of best practices will have a large impact on reducing GHG emissions. For example, if nonprocess plant electrical energy is reduced from 25 to $15 \%$ for the 40.0 million L/yr plant, GHG emissions/yr for the plant would be reduced by about $233,000 \mathrm{~kg}$ of $\mathrm{CO}_{2 \mathrm{e}} / \mathrm{yr}$.

The effects of changes in boiler efficiency on GHG emissions are weaker than that of improvements in nonprocess electrical energy use. Increasing boiler efficiency from 80 to $90 \%$, with changes in the boiler efficiency factor from 20 to $10 \%$ while holding the allowance for nonprocess electrical energy at $25 \%$, resulted in a decrease in plant energy from $21,637,000$ to $21,116,000$ 
Table 11. Effect of the values of the nonprocess factors for electricity usage and boiler efficiency on total process energy, specific energy consumption (SEC), and greenhouse gas (GHG) emissions for the base 40.0 million L/yr plant

\begin{tabular}{|c|c|c|c|c|c|c|c|}
\hline $\begin{array}{l}\text { Electricity } \\
\text { factor }(\%)\end{array}$ & $\begin{array}{l}\text { Natural } \\
\text { gas }(\%)\end{array}$ & $\begin{array}{c}\text { Total energy } \\
(\times 1 \text { million } \\
\mathrm{MJ} / \mathrm{yr})\end{array}$ & $\begin{array}{l}\mathrm{kg} \text { of } \mathrm{CO}_{2 \mathrm{e}}{ }^{1} \\
(\times 1 \text { million })\end{array}$ & $\begin{array}{l}\text { GHG contribution } \\
\text { from electricity } \\
\text { ( } \mathrm{g} \text { of } \mathrm{CO}_{2 \mathrm{e}} / \\
\mathrm{kg} \text { of milk) }\end{array}$ & $\begin{array}{l}\text { GHG contribution } \\
\text { from natural gas } \\
\text { (g of } \mathrm{CO}_{2 \mathrm{e}} / \\
\mathrm{kg} \text { of milk) }\end{array}$ & $\begin{array}{c}\text { SEC } \\
(\mathrm{MJ} / \mathrm{kg})\end{array}$ & $\begin{array}{l}\text { Total GHG } \\
\left(\mathrm{g} \text { of } \mathrm{CO}_{2 \mathrm{e}} /\right. \\
\mathrm{kg} \text { of milk) }\end{array}$ \\
\hline 25 & 20 & 21.637 & 3.633 & 81 & 10 & 0.54 & 91 \\
\hline 0 & 20 & 18.687 & 3.000 & 65 & 10 & 0.45 & 75 \\
\hline 5 & 20 & 19.227 & 3.080 & 67 & 10 & 0.48 & 77 \\
\hline 10 & 20 & 19.867 & 3.280 & 72 & 10 & 0.50 & 82 \\
\hline 15 & 20 & 20.457 & 3.400 & 75 & 10 & 0.51 & 85 \\
\hline 20 & 20 & 21.047 & 3.520 & 78 & 10 & 0.53 & 88 \\
\hline 40 & 20 & 23.407 & 4.000 & 90 & 10 & 0.59 & 100 \\
\hline 50 & 20 & 24.587 & 4.280 & 97 & 10 & 0.62 & 107 \\
\hline 25 & 0 & 20.596 & 3.600 & 81 & 9 & 0.54 & 90 \\
\hline 25 & 10 & 21.116 & 3.600 & 81 & 9 & 0.53 & 90 \\
\hline 25 & 30 & 22.157 & 3.680 & 81 & 11 & 0.55 & 92 \\
\hline 25 & 40 & 22.678 & 3.720 & 81 & 12 & 0.57 & 93 \\
\hline
\end{tabular}

${ }^{1} \mathrm{CO}_{2 \mathrm{e}}=\mathrm{CO}_{2}$ equivalent.

$\mathrm{MJ} / \mathrm{kg}$, a decrease in energy of $2 \%$ with a decrease in GHG emissions from 91 to $90 \mathrm{~g}$ of $\mathrm{CO}_{2 \mathrm{e}} / \mathrm{kg}$ of milk, or approximately $33,000 \mathrm{~kg} / \mathrm{yr}$.

Tan et al. (2011) recommended many strategies to reduce nonprocess electrical and fuel energy use and to lower GHG emissions. These include improvements to reduce natural gas consumption of a boiler, which would affect the value of the boiler efficiency factor in the simulator, or improvements to reduce electricity consumption, such as operating or reducing the power level of electric motor drives that affect unit operations such as homogenization, cold storage, and packaging. Other energy savings opportunities for steam systems, motor systems, compressed air systems, and pumps in dairy plants are discussed in Brush et al. (2011).

Various alternative energy management systems such as solar energy, cogeneration, heat pumps, and geothermal energy, as discussed in Tomasula and Nutter (2011) and Brush et al. (2011), have already been installed in many dairy plants throughout the United States. The process simulator may be used conduct feasibility testing of integration of these systems to a benchmarked facility to determine cost savings relative to a benchmarked process.

Strategies for CIP Operations. As shown in Tables 3 and 4, CIP processes contribute significantly to GHG emissions and energy usage of fluid milk processing plants. Several alternatives to conventional CIP operations that may lower the energy associated with CIP operations are discussed in Brush et al. (2011). Van Asselt et al. (2002) and Alvarez et al. (2010) demonstrated that critical analysis of CIP operations through monitoring and installation of sensors can significantly shorten cleaning times and reduce energy, wastewater volume, and detergent volume, thus allowing increases in processing time and production. Eide et al. (2003) showed that enzyme-based cleaning, one-phase alkaline cleaning, and membrane filtration reduced energy use compared with conventional CIP. Enzyme-based cleaners can reduce the chemical load of cleaning effluents in CIP (Graßhoff, 2002) and the environmental impacts contributing to eutrophication. Through development of suitable models, the fluid milk process simulator may be used to evaluate proposed alternatives to CIP as part of the fluid milk process model developed here.

\section{CONCLUSIONS}

A computer model for prediction of the energy use, GHG emissions, and costs of the fluid milk process was developed. This is a useful tool for processors to benchmark their current operations, regardless of plant size, to test the cost effectiveness of process and nonprocess-related plant upgrades for lowering energy use and $\mathrm{CO}_{2 \mathrm{e}}$ emissions and to test the effect on whole plant energy usage and $\mathrm{CO}_{2 \mathrm{e}}$ emissions of the addition of new technologies to an existing milk process. The simulator was validated by comparison of simulation results from literature and industry data. The modelpredicted carbon footprint of milk was $91 \mathrm{~g}$ of $\mathrm{CO}_{2 \mathrm{e}} /$ $\mathrm{kg}$ of milk, which is within $5 \%$ of the industry-reported value of $96 \mathrm{~g}$ of $\mathrm{CO}_{2 \mathrm{e}} / \mathrm{kg}$ of packaged milk obtained by LCA. The model also calculates the water used in each step of the fluid milk process but could not be validated due to a lack of data. This model is available upon request from the authors for educational purposes or for noncommercial use. It is available for download from the website http://www.ars.usda.gov/main/site_ main.htm?modecode $=19-35-47-00$. The model can be viewed and examined using the free evaluation version of SuperPro Designer, which can be downloaded from http://www.intelligen.com. 


\section{ACKNOWLEDGMENTS}

We thank Gail Barnes, formerly of the Innovation Center for US Dairy (Rosemont, IL), and Clay Detlefsen of the International Dairy Foods Association (Washington, DC) for their support of this project; members of the Dairy Plant Smart team for betatesting the simulation model and their suggestions for its improvement; and the dairy processors who shared their operating data to validate the model. We also thank Demitri Petrides (Intelligen Inc., Scotch Plains, NJ) for reviewing the manuscript.

\section{REFERENCES}

Alvarez, N., G. Daufin, and G. Gésan-Guiziou. 2010. Recommendations for rationalizing cleaning-in-place in the dairy industry: Case study of an ultra-high temperature heat exchanger. J. Dairy Sci. 93:808-821.

ASHRAE (American Society of Heating, Refrigerating and Air-Conditioning Engineers). 2007. 2007 ASHRAE Handbook: Heating, Ventilating, and Air-Conditioning Applications (I-P ed.). Knovel Corp., New York, NY.

Babcock \& Wilcox Company. 2005. Steam: Its Generation and Use. 41st ed. Babcock \& Wilcox Company, New York, NY.

Brush, A., E. Masanet, and E. Worrell. 2011. Energy efficiency improvement and cost saving opportunities for the dairy processing industry. An ENERGY STAR ${ }^{\circledR}$ Guide for Energy and Plant Managers. Lawrence Berkeley National Laboratory, Berkeley, CA. Sponsored by the US Environmental Protection Agency. Accessed Aug. 23, 2012. http://www.energystar.gov/ia/business/industry/ downloads/Dairy_Guide_Final.pdf.

Cashman, S., K. Dick, D. Przybylo, and W. Walter. 2009. Charting the course for sustainability at Aurora Organic Dairy. Report No. CSS09-03. University of Michigan, Ann Arbor.

Chandarana, D. I., B. C. Frey, L. E. Stewart, and J. F. Mattick. 1984. UHT milk processing - Effect on process energy requirements. J. Food Sci. 49:977-978.

Cheng, H., and A. Friis. 2007. Operability and flexibility of a milk production line. Food Bioprod. Process. 85:372-380.

Cole, R. A. 2004. Cold storage warehouses - An engineering overview. Accessed Aug. 23, 2012. http://seagrant.uaf.edu/map/workshops/ cold-storage/Cole.pdf.

Dalton, T. J., G. K. Criner, and J. Halloran. 2002. Fluid milk processing costs: Current state and comparisons. J. Dairy Sci. 85:984991.

Datta, N., A. J. Elliott, M. L. Perkins, and H. C. Deeth. 2002. Ultrahigh-temperature (UHT) treatment of milk: comparison of direct and indirect modes of heating. Aust. J. Dairy Technol. 57:211227.

Datta, N., M. G. Hayes, H. C. Deeth, and A. L. Kelly. 2005. Significance of frictional heating for effects of high pressure homogenization on milk. J. Dairy Res. 72:393-399.

Deru, M. and P. Torcellini. 2007. Source energy and emission factors for energy use in buildings. Technical report NREL/TP-55038617, Revised June 2007. National Renewable Energy Laboratory (NREL), Golden, CO.

Doty, S., and W. C. Turner. 2009. Energy Management Handbook. 7th ed. The Fairmount Press, Lilburn, GA.

Eide, M. H., J. P. Homleid, and B. Mattsson. 2003. Life cycle assessment (LCA) of cleaning-in-place processes in dairies. Lebenson. Wiss. Technol. 36:303-314.

EPA (Environmental Protection Agency). 2012. Inventory of U.S. Greenhouse Gas Emissions and Sinks: 1990-2010. EPA 430-R-12001. United States Environmental Protection Agency, Washington, DC. Accessed Sep. 11, 2012. http://www.epa.gov/climatechange/
Downloads/ghgemissions/US-GHG-Inventory-2012-Main-Text. pdf.

Erba, E. M., R. D. Aplin, and M. W. Stephenson. 1997. An analysis of processing and distribution productivity and costs in 35 fluid milk plants. Cornell Program on Dairy Markets and Policy. Research Bulletin 97-03. Accessed Aug. 8, 2012. http://dairy.wisc.edu/ pubPod/pubs/RB9703.pdf.

FAO (Food and Agriculture Organization of the United Nations). 2010. Greenhouse gas emissions from the dairy sector: A life cycle assessment. FAO, Rome, Italy.

FDA (Food and Drug Administration). 2011. US Department of Health and Human Services. Public Health Service. Grade "A", Pasteurized Milk Ordinance. 2011 Revision. Accessed Nov. 12, 2012. http://www.fda.gov/downloads/Food/ FoodSafety/Product-SpecificInformation/MilkSafety/National ConferenceonInterstateMilkShipmentsNCIMSModelDocuments/ UCM291757.pdf.

Graßhoff, A. 2002. Enzymatic cleaning of milk pasteurizers. Food Biprod. Process. 80:247-252.

Hoffman, W., C. Kiesner, I. Clawin-Rädecker, D. Martin, K. Einhoff, P. C. Lorenzen, H. Meisel, P. Hammer, G. Suhren, and P. Teufel. 2006. Processing of extended shelf-life milk using microfiltration. Int. J. Dairy Technol. 59:229-235.

IDFA (International Dairy Foods Association). 2007. DAIRY Facts Book, 2007 Edition. IDFA, Washington, DC.

IPCC (Intergovernmental Panel on Climate Change). 2007. Climate Change 2007: Synthesis Report. Contribution of working Groups I, II and III to the Fourth Assessment Report of the Intergovernmental Panel on Climate Change. Core Writing Team, R. K. Pachauri, and A. Reisinger, ed. IPCC, Geneva, Switzerland. Accessed Sep. 18, 2012. http://ipcc.ch/pdf/assessment-report/ar4/ syr/ar4_syr.pdf.

Jacobs, S. L., and G. K. Criner. 1990. Milk Processing and Distribution Costs: The Maine Model. Maine Agricultural Experiment Station, Technical Bulletin 140, May 1990. Department of Agricultural and Resource Economics, University of Maine, Orono.

Juriaanse, A. J. 1999. Examples from dairy science show how descriptive science can be transferred into prescriptive knowledge. Trends Food Sci. Technol. 10:303-306.

Kulozik, U. 2007. Procedures for the manufacture of milk with an extended shelf-life. Current techniques and new options. Deutsche Milchwirtschaft 58:268-271.

Nicol, R. S., N. Kydas, and L. J. Robertson. 2005. World standard energy practice. Pages 3-10 in Energy Use in Dairy Processing. Bulletin of the International Dairy Federation. 401/2005. International Dairy Federation, Brussels, Belgium.

NRCan (Natural Resources Canada). 2001. Energy performance indicator report: Fluid milk plants. NRCan, Ottawa, ON, Canada.

Persson, P. A. 1987. Chapter 12: Dairy Plant. Pages 87-91 in Food Factories: Processes, Equipment, Costs. A. Bartholomai, ed. VCH Verlagsgesellschaft mbH, Weinheim, Germany.

Peters, M. S., K. D. Timmerhaus, and R. E. West. 2003. Plant Design and Economics for Chemical Engineers. 5th ed. McGraw-Hill Book Co., New York, NY.

Petrides, D., R. Cruz, and J. Calandranis. 1998. Optimization of wastewater treatment facilities using process simulation. Comput. Chem. Eng. 22(Suppl. 1):S339-S346.

Ray, M. S., and M. G. Sneesby. 1998. Chemical Engineering Design Project: A Case Study Approach. 2nd ed. Gordon and Breach Science Publishers. Amsterdam, the Netherlands.

Santamarina, V. E. 1997. Modeling and optimization of a municipal treatment plant using EnviroPro Designer. Environ. Prog. $16: 268-273$.

Tan, A. J., D. W. Nutter, and F. Milani. 2011. GHG emissions and energy use from a multi-product dairy processing plant. 2011 ECTC Proc. ASME Early Career Technical Conference, Fayetteville, AR. Accessed Mar. 6, 2013. http://districts.asme.org/DistrictE/ ECTCPapers/2011Papers/ECTCpaper-AR-AJTan.pdf.

Thoma, G., J. Popp, D. Nutter, D. Shonnard, R. Ulrich, M. Matlock, D. S. Kim, Z. Neiderman, N. Kemper, C. East, and F. Adom. 2012. Greenhouse gas emissions from milk production and con- 
sumption in the United States: A cradle-to-grave life cycle assessment circa 2008. Int. Dairy J. http://dx.doi.org/10.1016/j. idairyj.2012.08.013.

Toepfl, S., A. Mathys, V. Heinz, and D. Knorr. 2006. Review: Potential of high hydrostatic pressure and pulsed electric fields for energy efficient and environmentally friendly food processing. Food Rev. Int. 22:405-423.

Tomasula, P. M., S. Mukhopadhyay, N. Datta, A. C. S. Porto-Fett, J. E. Call, J. B. Luchansky, J. Renye, and M. Tunick. 2011. Pilotscale crossflow-microfiltration and pasteurization to remove spores of Bacillus anthracis (Sterne) from milk. J. Dairy Sci. 94:42774291. http://dx.doi.org/10.3168/jds.2010-3879.
Tomasula, P. M., and D. W. Nutter. 2011. Mitigation of greenhouse gas emissions in the production of fluid milk. Adv. Food Nutr. Res. 62:41-88.

US DOE (United States Department of Energy). 2010. Industrial Assessment Centers. Accessed Sep. 16, 2012. http://iac.rutgers.edu/. Van Asselt, A. J., G. Van Houwelingen, and M. C. Te Giffel. 2002 Monitoring system for improving cleaning efficiency of cleaningin-place processes in dairy environments. Food Bioprod. Process. $80: 276-280$

Xu, T., and J. Flapper. 2009. Energy use and implications for efficiency strategies in global fluid-milk processing industry. Energy Policy 37:5334-5341. 